DOI: https://doi.org/10.32838/2523-4803/70-2-26

УДК 334.021:658:69.009

\title{
Величко В.A.
}

кандидат економічних наук,

асистент кафедри підприємництва та бізнес адміністрування,

Харківський національний університет

міського господарства імені О.М. Бекетова

Velychko Volodymyr

O.M. Beketov National University of Urban Economy in Kharkiv

\section{РОЗРОБКА ДОРОЖНЬОЇ КАРТИ ЗАБЕЗПЕЧЕННЯ ЕФЕКТИВНОСТІ РІВНЯ СТЕЙКХОЛДЕРНИХ ВІДНОСИН БУДІВЕЛЬНИХ ПІДПРИЕМСТВ}

Метою дослідження є розроблення дорожньої карти забезпечення ефективності рівня стейкхолдерних відносин будівельних підприємств. Запропоноване авторське визначення стейкхолдерів будівельних підприємств характеризує їх як фізичних $і$ (або) юридичних осіб або груп осіб, які взаємодіють у будівельній сфері. Ірунтуючись на визначенні стейкхолдерів будівельних підприємств, для забезпечення розвитку стейкхолдерних відносин, протидії негативним явищам пропонуємо локальні стратегії. Здійснено оиінювання інтегрального показника рівня стейкхолдерних відносин будівельних підприємств. Побудовано дорожню карту забезпечення ефективності рівня стейкхолдерних відносин будівельних підприємств. Розроблено дорожню карту забезпечення ефективності рівня стейкхолдерних відносин будівельних підприємств.

Ключові слова: стейкхолдери, стейкхолдерні відносини, будівельні підприємства, рівень стейкхолдерних відносин, локальні стратегії, дорожні карти.

Постановка проблеми. Сучасні умови господарювання потребують переосмислення підходів до розвитку будівельних підприємств. У цьому процесі особливого значення набуває зростання ефективності взаємодії з різними групами стейкхолдерів, які впливають на їх діяльність. За останні роки зростає значення зацікавлених осіб, їх взаємодії для будівельних підприємств. Проте на їх більшості на низькому рівні досліджуються та враховуються особливості взаємодії зі стейкхолдерами, не визначаються кількісні параметри для прийняття обгрунтованих управлінських рішень, не формується стейкхолдерно орієнтована стратегія розвитку будівельних підприємств. Для вирішення представлених складних проблем актуально розробити дорожню карту забезпечення ефективності рівня стейкхолдерних відносин будівельних підприємств.

Аналіз останніх досліджень і публікацій. В наявних наукових розробках досліджуються та обгрунтовуються теоретичні положення щодо визначення стейкхолдерів підприємств. Заслуговують на увагу розробки Е. Фрімена, який визначає стейкхолдерів як будь-яку групу або індивідуумів, що можуть впливати на досягнення організацією своєї мети або на яких може впливати досягнення організацією своєї мети [1]. На противагу попередньому досліднику П. Данселмі характеризує стейкхолдерів з позиції функціонального підходу та визначає їх як людей або групи, які добровільно або ненавмисно піддаються впливу ризику, що виникає у зв'язку з діями фірми [2, с. 27]. Подібну точку зору поділяють А. Аммарі [3, с. 151], Л. Гаценко [4], Р. Акофф [5-7], Д. Кліленд [8]. На результативних характеристиках, що забезпечує взаємодія стейкхолдерів, зосереджують увагу Т. Дональдсон і Л. Престон, які визначають зацікавлених осіб з позиції напрямів ідентифікації через фактичну або потенційну шкоду та вигоду, яку вони відчувають або очікують випробувати в результаті дії фірми або їі бездіяльності [9, с. 65]. На формуванні напрямів та особливостей управління стейкхолдерами фокусує увагу Дж. Пост [10]. На структурних складових частинах під час визначення стейкхолдерів наполягають інші дослідники [11-15]. Разом зі значною кількістю наукових розробок залишаються невирішеними питання формування теоретико-методичної платформи щодо визначення стейкхолдерів будівельних підприємств та розроблення на цій основі дорожньої карти забезпечення ефективності рівня стейкхолдерних відносин.

Формулювання цілей статті. Метою дослідження $€$ розроблення дорожньої карти забезпечення ефективності рівня стейкхолдерних відносин будівельних підприємств.

Для досягнення поставленої мети вирішуються такі завдання:

- формування напрямів розроблення дорожньої карти забезпечення ефективності рівня стейкхолдерних відносин будівельних підприємств; 
- визначення стейкхолдерів будівельних підприємств;

- оцінювання рівня стейкхолдерних відносин будівельних підприємств;

- формування пропозицій щодо зростання рівня стейкхолдерних відносин на основі розробленої дорожньої карти.

Виклад основного матеріалу. В результаті узагальнення та систематизації наявних теоретико-методичних підходів запропоновано авторське визначення стейкхолдерів будівельних підприємств. Отже, вони характеризуються як фізичні й (або) юридичні особи або групи осіб, що взаємодіють у будівельній сфері на основі стратегічних контурів і соціальних напрямів та визначаються функціональними, результуючими, структурними, процесними, стратегічними, комплексними ознаками, взаємовідносини яких мають певний рівень ризику й загроз, що дає змогу сформувати підрядні відносини в капітальному будівництві, здійснити архітектурний контроль, відповідні розрахунки, що забезпечено проєктною документацією, матеріальними й трудовими ресурсами. Обгрунтовані наукові положення $\epsilon$ елементом створення теоретико-методологічної платформи формування та реалізації стейкхолдерно орієнтованої стратегії управління будівельними підприємствами.

Базуючись на визначенні стейкхолдерів будівельних підприємств, для забезпечення розвитку стейкхолдерних відносин, протидії негативним явищам пропонуємо такі локальні стратегії.

1) Антикризова стратегія, що характеризується відсутністю, незначним, низьким, або несуттєвим рівнем інтегрального показника стейкхолдерних відносин, що приводить до подібних рівнів інвестиційної привабливості будівельних підприємств. У рамках цієї стратегії пропонується вжиття заходів протидії кризовим явищам щодо невиконання або низького рівня формування й виконання договірних зобов'язань між стейкхолдерами, реалізації взаємодії стейкхолдерів за різними напрямами функціонування будівельних підприємств, незабезпечення або низької ефективності реалізації корпоративного управління в системі взаємовідносин зацікавлених осіб, стратегічних напрямів, формування й реалізації соціально-економічного та інноваційного розвитку під час взаємодії із зацікавленими особами, не визначається або на низькому рівні формується інформаційно-аналітичне забезпечення стратегічного стану будівельних підприємств.

2) Стратегія стабілізації, що визначається помірним рівнем інтегрального показника стейкхолдерних відносин, який є одним із факторів забезпечення помірного рівня інвестиційної привабливості будівельних підприємств. У рамках представленої локальної стейкхолдерно орієнтованої стратегії управління запропоновані заходи щодо забезпечення виконання окремих договірних зобов'язань, підвищення ефективності окремих напрямів взаємодії зі стейкхолдерами, реалізації корпоративного управління будівельними підприєм- ствами, що дає змогу забезпечити їх функціонування й ефективність взаємодії із зацікавленими особами, формування та реалізації окремих стратегічних напрямів, напрямів соціально-економічного та інноваційного розвитку, визначення окремих показників, що характеризують стратегічний стан будівельних підприємств.

3) Стратегія зростання, що характеризується суттєвим, високим, значним або абсолютним рівнем інтегрального показника стейкхолдерних відносин, що забезпечить реалізацію можливостей для підвищення інвестиційної привабливості будівельних підприємств. У цьому контексті відбувається вжиття заходів, спрямованих на системне виконання договірних зобов'язань між стейкхолдерами, комплексну реалізацію напрямів взаємодії із зацікавленими особами, здійснення корпоративного управління щодо взаємодії зі стейкхолдерами, яке базується на принципах забезпечення ефективності, партнерства, результативності діяльності, формування та реалізації системи стратегічних напрямів, напрямів соціально-економічного й інноваційного розвитку, визначення комплексу показників, що характеризують стратегічний стан будівельних підприємств.

Для забезпечення розвитку стейкхолдерних відносин та підвищення ефективності їх формування й реалізації розроблено аналітичний блок, який включає формування квазиметричних моделей переходу чинників та інших елементів інформаційного блоку в показники. В результаті будується багаторівнева система показників, що дає змогу розробити та реалізувати методологічний підхід до інтегрального оцінювання рівня стейкхолдерних відносин будівельних підприємств (оцінний блок). Визначається інтегральний показник рівня стейкхолдерних відносин, значення якого варіюється від 0 до 10 й більше.

Якщо його значення менше 3 , то застосовується локальна антикризова стейкхолдерно орієнтована стратегія управління будівельними підприємствами. Значення інтегрального показника рівня стейкхолдерних відносин, що перебуває в проміжку від 3,01 до 7, дає змогу запропонувати локальну стейкхолдерно орієнтовану стратегію стабілізації. Якщо інтегральний показник перевищує значення 7,01, то застосовується стратегія зростання.

У дослідженні здійснено оцінювання інтегрального показника рівня стейкхолдерних відносин будівельних підприємств як узагальнюючого чинника визначення рівня їх ефективності, а саме АТ «ХК «Київміськбуд» має 5,84; ВАТ «Броварський завод будівельних конструкцій» - 4,85; АТ «КДБК»- 4,97; АТ «Трест Житлобуд-1» - 4,96; ТОВ Будівельна компанія «Міськжитлобуд» - 4,39; ПрАТ «Нерухомість столиці» - 4,8; ТОВ «Житлобуд-2» - 4,82; Українська державна будівельна корпорація «УкрБуд» - 4,9; Будівельна група «Фундамент» $-4,82$.

Залежно від запропонованих локальних стратегій, здійснених розрахунків інтегрального показника рівня стейкхолдерних відносин розробляється та реалізується дорожня карта забезпечення ефективності рівня 


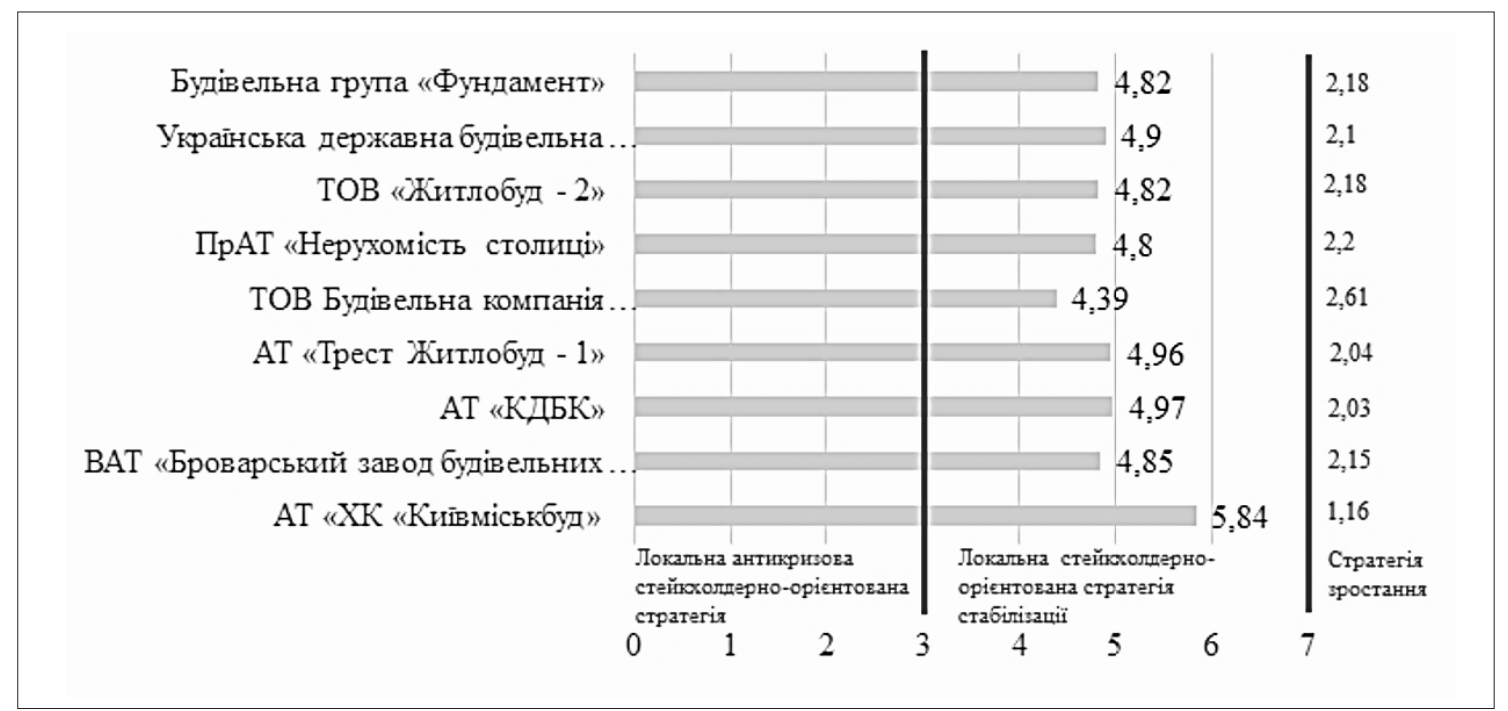

Рис. 1. Дорожня карта забезпечення ефективності

рівня стейкхолдерних відносин будівельних підприсмств, відн. од.

Джерело: розроблено автором

стейкхолдерних відносин будівельних підприємств, відповідних заходів (рис. 1).

Відповідно до розробленої дорожньої карти зроблено висновок про те, що на всіх будівельних підприємствах запропонована локальна стейкхолдерно орієнтована стратегія стабілізації щодо їх управління. Водночас для реалізації стратегії зростання необхідно створити умови для підвищення ефективності рівня стейкхолдерних відносин на досліджених будівельних підприємствах та збільшення відповідного інтегрального показника вище 7,01 відн. од.

Висновки. Отже, в результаті дослідження вдосконалено понятійний апарат економічної науки, зокрема введено в функціональне поле ефективного управління підприємствами поняття «стейкхолдери будівельних підприємств», що визначається сукупністю функціональних, результуючих, структурних, процесних, стратегічних, комплексних ознак, взаємовідносини яких мають певний рівень ризику й загроз, формують стратегічні напрями та забезпечують ефективність діяльності будівельних підприємств, що дає змогу сформувати підрядні відносини в капітальному будівництві, здійснити архітектурний контроль, відповідні розрахунки, які забезпечені проєктною документацією, матеріальними й трудовими ресурсами.

В результаті оцінювання визначено інтегральний показник рівня стейкхолдерних відносин буді- вельних підприємств, який дає змогу встановити, що найбільшим значенням цього критерію характеризувалось АТ «ХК «Київміськбуд». Проте, як на інших будівельних підприємствах, воно визначалось помірним рівнем, який свідчить про безсистемність заходів щодо формування та реалізації договірних зобов'язань, взаємодії стейкхолдерів за сферами функціонування будівельних підприємств, формування та реалізації корпоративного управління в системі взаємовідносин між зацікавленими особами, стратегічних напрямів, безсистемність формування та реалізації соціально-економічного та інноваційного напрямів під час взаємодії із зацікавленими особами, відсутність системи формування та визначення показників стратегічного стану будівельних підприємств, забезпечення їх перманентного моніторингу. Отже, особливого значення набувають розроблення та вжиття науково обгрунтованих заходів щодо зростання ефективності та рівня взаємодії зі стейкхолдерами будівельних підприємств шляхом реалізації стейкхолдерно орієнтованої стратегії.

Розроблено дорожню карту забезпечення ефективності рівня стейкхолдерних відносин будівельних підприємств, яка дала змогу об'єднати локальні стейкхолдерно орієнтовані стратегії їх управління та результати інтегрального оцінювання рівня стейкхолдерних відносин.

\section{Список літератури:}

1. Freeman E. Strategic Management: A Stakeholder Approach, Pitman, Boston, 1984. P. 34.

2. D'Anselmi P. Values and Stakeholders in an Era of Social Responsibility, Free Press, New York, 2011. P. 27.

3. Аммарі А.О. Класифікація стейкхолдерів на основі взаємних очікувань. Актуальні проблеми економіки. 2012. № 8. C. $150-155$.

4. Гаценко Л.В. Теорія зацікавлених сторін (стейкхолдерів): історія розвитку та проблемні питання для подальших досліджень. URL: https://www.google.com/url?sa=t\&rct=j\&q=\&esrc=s\&source=web\&cd=1\&cad (дата звернення: 15.03.2020). 
5. Акофф Р. Планирование в больших экономических системах / пер. с англ. Москва : Советское радио, 1972. 223 с.

6. Акофф Р., Эмери Ф. О целеустремленных системах / пер. с англ. Москва : Советское радио, 1974. 272 с.

7. Акофф Р. Искусство решения проблем / пер. с англ. Москва : Мир, 1982. 224 с.

8. Клилэнд Д. Управление заинтересованными лицами проекта / пер. с англ. Ч. 1. Гл. 4. Москва, 2004. С. 73-91.

9. Donaldson T., Preston L. The stakeholder theory of the Corporation: concepts, evidence, and implications. Academy of Management Review. 1997. № 1. P. 65-66.

10. Post J.E., Preston L., Sachs S. Redefining the corporation: stakeholder management and organizational wealth, Stanford university press, California, 2002. P. 320.

11. Ареф'єва О.В., Комарецька П.В. Інтереси стейкхолдерів в організаційному забезпеченні стратегічного управління фінансовим потенціалом підприємств. Актуальні проблеми економіки. 2008. № 9. С. 80.

12. Зінченко А.Г., Саприкіна М.А. Соціальна відповідальність в Україні: погляди різних стейкхолдерів. Київ : Регіональний аспект, 2008. 60 c.

13. Mitchell R.K., Agle B.R., Wood D.J. Toward a theory of stakeholder identification and salience: defining the principle of who and what really counts. Academy of Management Review. 1997. Vol. 22. № 4. P. 853-886.

14. Newbould G., Luffman G. Successful Business Politics, Gower, London, 1989. P. 78

15. Саприкіна М.А., Каба Д.В. Діалог зі стейкхолдерами: рекомендації компаніям. Київ : Фарбований лист, 2011. 475 с.

\section{References:}

1. Freeman E. (1984) Strategic Management: A Stakeholder Approach, Pitman, Boston, p. 34.

2. D’Anselmi P. (2011), Values and Stakeholders in an Era of Social Responsibility, Free Press, New York, p. 27.

3. Ammari A.O. (2012) Klasyfikatsiia steikkholderiv na osnovi vzaiemnykh ochikuvan [Stakeholder classification based on mutual expectations]. Aktualni problemy ekonomiky, no. 8, pp. 150-155.

4. Hatsenko L.V. Teoriia zatsikavlenykh storin (steikkholderiv): istoriia rozvytku ta problemni pytannia dlia podalshykh doslidzhen [Stakeholder Theory: Development History and Challenging Issues for Further Research]. Available at: https:/www.google.com/url?sa=t\&rct=j\&q=\&esrc=s\&source=web\&cd=1\&cad (accessed: 15.03.2020).

5. Akoff R. (1972) Planirovanie v bolshikh ekonomicheskikh sistemakh [Planning in large economies]. Moskow : Sovetskoe radio, $223 \mathrm{p}$.

6. Akoff R., Emeri F. (1974) O czeleustremlyonnykh sistemakh [About purposeful systems]. Moskow : Sovetskoe radio, 272 p.

7. Akoff R. (1982) Iskusstvo resheniya problem [The art of problem solving]. Moskow : Mir, $224 \mathrm{p}$.

8. Klilend D. (2004) Upravlenie zainteresovannymi liczami proekta [Project stakeholder management]. Moskow, p. 73-91.

9. Donaldson T., Preston L. (1997) The stakeholder theory of the Corporation: concepts, evidence, and implications, Academy of Management Review, no. 1, p. 65-66.

10. Post J.E., Preston L., Sachs S. (2002) Redefining the corporation: stakeholder management and organizational wealth. Stanford university press, California, p. 320

11. Arefieva O.V., Komaretska P.V. (2008) Interesy steikkholderiv v orhanizatsiinomu zabezpechenni stratehichnoho upravlinnia finansovym potentsialom pidpryiemstv [Stakeholder interests in the organizational support of strategic management of financial potential of enterprises]. Aktualni problemy ekonomiky, no. 9, p. 80.

12. Zinchenko A.H., Saprykina M.A. (2008) Sotsialna vidpovidalnist v Ukraini: pohliady riznykh steikkholderiv [Social responsibility in Ukraine: views of different stakeholders]. Kiev: Rehionalnyi aspekt, 60 p.

13. Mitchell R.K., Agle B.R., Wood D.J. (1997) Toward a theory of stakeholder identification and salience: defining the principle of who and what really counts / Academy of Management Review, vol. 22, no. 4, pp. 853-886.

14. Newbould G., Luffman G. (1989) Successful Business Politics, Gower, London, p. 78.

15. Saprykina M.A., Kaba D.V. (2011) Dialoh zi steikkholderamy: rekomendatsii kompaniiam [Stakeholder dialogue: recommendations for companies]. Kiev : Farbovanyi lyst. 475 p.

\section{РАЗРАБОТКА ДОРОЖНОЙ КАРТЫ ОБЕСПЕЧЕНИЯ ЭФФЕКТИВНОСТИ УРОВНЯ СТЕЙКХОЛДЕРНЫХ ОТНОШЕНИЙ СТРОИТЕЛЬНЫХ КОМПАНИЙ}

Целью исследования является разработка дорожной карты обеспечения эффективности уровня стейкхолдерных отношений строительных предприятий. Предложенное авторское определение стейкхолдеров строительных предприятий характеризует их как физических и (или) юридических лии или групп лиц, взаимодействующих в строительной сфере. Основываясь на определении стейкхолдеров строительных предприятий, для обеспечения развития стейкхолдерных отношений, противодействия негативным явлениям предлагаем локальные стратегии. Осуществлено оченивание интегрального показателя уровня стейкхолдерных отношений строительных предприятий. Построена дорожная карта обеспечения эффективности уровня стейкхолдерных отношений строительных предприятий. Разработана дорожная карта обеспечения эффективности уровня стейкхолдерных отношений строительных предприятий.

Ключевые слова: стейкхолдеры, стейкхолдернье отношения, строительные предприятия, уровень стейкхолдерных отношений, локальные стратегии, дорожные карты. 


\section{DEVELOPMENT OF THE ROAD CARD FOR ENSURING EFFICIENCY OF THE LEVEL OF STAKEHOLDER RELATIONS OF CONSTRUCTION COMPANIES}

The aim of the study is to develop a roadmap for ensuring the effectiveness of the level of stakeholders of relations between construction enterprises. To achieve this goal, the following tasks are solved: the formation of directions for the development of a road map to ensure the effectiveness of the level of stakeholder relations of construction enterprises; identification of stakeholders in construction enterprises; assessment of the level of stakeholder relations of construction enterprises; formation of proposals for increasing the level of stakeholder relations based on the developed roadmap. The author's definition of stakeholders of construction enterprises is proposed. They are characterized as individuals and (or) legal entities or groups of people interacting in the construction industry on the basis of strategic contours and social areas and are defined by functional, resulting, structural, process, strategic, complex features, the relationships of which have a certain the level of risk and threats, allows you to form a contractual relationship in capital construction, to carry out architectural control Corresponding calculations, ensuring the project documentation, material and labor resources. Based on the definition of stakeholders of construction enterprises, local strategies are proposed to ensure the development of stakeholder relations and counteract negative phenomena. As a result of evaluating the integral indicator of the level of stakeholder relations of construction enterprises, it was found that the highest value of this criterion was characterized by JSC HC "Kievgorstroy". However, as in other construction enterprises, it was determined by a moderate level. A road map has been built to ensure the effectiveness of the level of stakeholder relations of construction enterprises. A roadmap has been developed to ensure the effectiveness of the level of stakeholder relations of construction enterprises, which made it possible to combine local stakeholder-oriented strategies for their management and the results of an integrated assessment of the level of stakeholder relations.

Key words: stakeholder relations, social corporate responsibility, construction enterprises, stakeholders, system factor, integrated indicator, economic and mathematical modeling, adequacy criteria. 